\title{
THE INFLUENCE OF DOMESTIC LEGAL TRADITIONS ON THE GENDER JURISPRUDENCE OF INTERNATIONAL CRIMINAL TRIBUNALS
}

\author{
Valerie Oosterveld ${ }^{*}$
}

\section{Keywords}

Legal traditions, international criminal tribunals, gender jurisprudence

International criminal law is often seen as more progressive than many domestic legal traditions in its consideration of gender-based crimes such as rape. That said, domestic legal traditions have profoundly influenced how international criminal law has addressed gender-based crimes, especially crimes of sexual violence. In turn, international criminal law has also, to a lesser extent, influenced domestic law on gender-based crimes, again especially with respect to sexual violence. This seems to indicate an ongoing dialogue on sexual violence between the international and national spheres, but a closer examination raises questions about the appropriateness of that exchange. For example, have the correct domestic laws been considered when searching for international general principles of law on rape? Has gender-based discrimination in domestic laws been taken into account when considering the lessons those laws provide to international criminal law? And, perhaps most central to the consideration of whether there should be a flow of influence from the domestic to the international and back to the domestic: are the circumstances of international criminal law-namely the context of genocide, crimes against humanity or war crimes-so different from domestic circumstances that there can be no useful comparison?

This article begins with an examination of two examples of the flow from domestic to international criminal law. The first example relates to how rape has been defined by international criminal courts and tribunals. It demonstrates that, after an initial rejection of engagement with the domestic sphere, international criminal law has cautiously (in the case of the International Criminal Court) or fully (in certain cases before the International Criminal Tribunals for the

\footnotetext{
Associate Professor, Faculty of Law, University of Western Ontario. The author wishes to thank Professor Margaret Martin, the CJICL 2013 conference participants, the CJICL's reviewers and editors for their helpful comments, and the Social Sciences and Humanities Research Council of Canada for its funding to support the research for this paper.
}

Copyright $\odot$ the Author(s).

This work is licensed under a Creative Commons Attribution-NonCommercial-NoDerivs 3.0 License. 
Former Yugoslavia and Rwanda and the Special Court for Sierra Leone) embraced common domestic definitions of rape. The second example stems from the manner in which two international criminal tribunals dismissed evidence of sexual violence, seemingly influenced by widely-held domestic misconceptions about rape and sexual violence. Both examples demonstrate that, while there are positive aspects of the flow from the domestic to the international-for example, through the adaptation of domestic criminal procedures crafted to minimise retraumatisation of sexual violence survivors-there are also dangers. This is because domestic approaches to sexual violence contain within them certain assumptions, for example that rape is mainly a 'private' or opportunistic act, or that rape allegations against accused persons are somehow both less reliable and more damaging. These assumptions tend to be inaccurate and therefore harmful when they form the basis of legal reasoning at the domestic level. When transposed to the international level, they not only lead to flawed judgments, they also set regressive precedent.

This paper then turns to a discussion of the flow from international to domestic criminal law. It examines how domestic implementation of the Rome Statute of the International Criminal Court (ICC) and its Elements of Crimes, or domestic interpretation of the judgments of international criminal tribunals, present the possibility that outdated domestic legislation on sexual violence will be revised on a widespread basis. However, here again caution is needed. The international law on rape, in particular, is not entirely clear-can it provide a helpful road map for domestic reform? The answer to this will depend, it seems, on the state of domestic law on sexual violence prior to the reform.

This paper concludes that international and domestic criminal laws on sexual violence are indeed linked, but that they are not, and should not, be interchangeable. The International Criminal Tribunal for Rwanda (ICTR), in the first international criminal judgment considering the definition of rape, created a strong demarcation between international and domestic criminal law. This demarcation has since been eroded, creating a flow from the domestic to the international and back again. This conversation may assist in adding clarity and certainty to under-theorised aspects of sexual violence in international and domestic law. However, it may also add confusion where relatively dissimilar contexts (such as peacetime and war time) are treated as similar or where underlying gender-based discrimination is not acknowledged and addressed.

\footnotetext{
1 Prosecutorv Akayesu (Trial Judgment) (International Criminal Tribunal for Rwanda, Trial Chamber I, Case No ICTR-96-4-T, 2 September 1998) paras 596-7, 686-7 (Akayesu).
} 


\section{The influence of domestic law on international criminal law}

\subsection{The definition of rape}

Domestic law has had a significant influence on how international criminal courts and tribunals have defined and characterised the prohibited act of rape and other forms of sexual violence. The International Criminal Tribunals for the Former Yugoslavia and Rwanda, and the states negotiating the Elements of Crimes for the ICC, were the first to elaborate the actus reus and mens rea for rape as a prohibited act within genocide, crimes against humanity and war crimes. The end result has not been one single approach to the elements of rape, but rather four different approaches reflecting varying levels of engagement with domestic law.

The first international criminal tribunal to consider the elements of rape was the ICTR, in the case of Prosecutor v Jean-Paul Akayesu. As there was 'no commonly accepted definition' of rape in international law at that time, the ICTR's Trial Chamber looked to the domestic context for guidance. ${ }^{2}$ It found that certain national jurisdictions define rape as non-consensual intercourse. ${ }^{3}$ However, it also reasoned that it was important to include acts [in the definition of rape] which involve the insertion of objects and/or the use of bodily orifices not considered to be intrinsically sexual', as this was a common form of humiliation and harm during the Rwandan genocide. ${ }^{4}$ The Trial Chamber concluded that 'the central elements of the crime of rape cannot be captured in a mechanical description of objects and body parts, ${ }^{5}$ presumably rejecting domestic approaches containing such descriptions. ${ }^{6}$ The Trial Chamber preferred an approach similar to that found in the Convention Against Torture and Other Cruel, Inhuman and Degrading Treatment or Punishment, which 'does not catalogue specific acts in its definition of torture', focusing instead on the conceptual framework of statesanctioned violence." It felt that '[t]his approach is more useful in international

\footnotetext{
2 Ibid, para 596.

3 Ibid, paras 596, 686.

4 Ibid.

5 Ibid, paras 597, 687.

6 See the domestic definitions referring to body parts in Prosecutor v Furundžija (Trial Judgment) (International Criminal Tribunal for the Former Yugoslavia, Trial Chamber II, Case No IT-95-17/1-T, 10 December 1998) para 180 (Furundžija). The Akayesu trial judgment did not indicate which domestic definitions had been considered.

${ }^{7}$ Akayesu, above n 1, paras 597, 687.
} 
law.'

The Akayesu Trial Chamber seemed to come to the conclusion that there needed to be a specific international definition of rape for two reasons: first, because 'rape [during genocide] is a form of aggression' and the aim of the international definition should be to capture that aggression from the victim's perspective (the invasion of the victim's body); ${ }^{9}$ and second, in order to respect 'cultural sensitivities involved in public discussion of intimate matters' and the 'inability of [some] witnesses to disclose graphic anatomical details of sexual violence they endured.10 ${ }^{10}$ In other words, it appears that the Trial Chamber felt that the context of genocide (or other international crimes) was so different from that of 'common' domestic rape that domestic methods of defining the crime were not comparable or applicable. The Trial Chamber thus made a strong demarcation between domestic and the international approaches to defining rape. ${ }^{11}$ It therefore adopted a definition of rape meant specifically for international criminal law: 'a physical invasion of a sexual nature, committed on a person under circumstances which are coercive."12 One major difference between this definition and those at domestic law is that rape can be understood as involving forms of violence not involving penetration, such as sexual mutilation. ${ }^{13}$

The second tribunal to consider the definition of rape was the International Criminal Tribunal for the Former Yugoslavia (ICTY). While the ICTY began by following the Akayesu approach, ${ }^{14}$ it fundamentally shifted its analysis shortly after, in Prosecutor v Furundzija. In that case, the Prosecutor, and then the ICTY Trial Chamber, took a very different approach to that found in Akayesu.

\footnotetext{
8 Ibid, para 597.

9 Ibid. See also A-M de Brouwer, Supranational Criminal Prosecution of Sexual Violence: The ICC and the Practice of the ICTY and the ICTR (2005) 107-8, who points out that this definition defines rape by what it does to the victim, rather than from the perspective of the perpetrator, and that this is consistent with the way the prohibited acts of murder and torture are defined in international criminal law. This view was confirmed by one of the Akayesu trial judges, who has indicated that the definition of rape in Akayesu was intentionally worded so as to change 'the law's perception of women's experiences of sexual violence': N Pillay, 'Equal Justice for Women: A Personal Journey' (2008) $50 \mathrm{Az}$ LR 657, 666-7.

${ }^{10}$ Akayesu, above n 1, para 687.

${ }^{11}$ Ibid, paras 596-7.

12 Ibid, para 598.

${ }^{13}$ De Brouwer, above n 9, 107. This approach was subsequently followed by the ICTR: Prosecutor v Musema (Trial Judgment and Sentence) (International Criminal Tribunal for Rwanda, Trial Chamber I, Case No ICTR-96-13-A, 27 January 2000) paras 226-8 (Musema).

${ }^{14}$ Prosecutor v Delalić (Trial Judgment) (International Criminal Tribunal for the Former Yugoslavia, Trial Chamber, Case No IT-96-21-T, 16 November 1998) para 479.
} 
The Prosecutor proposed that rape be defined in terms of penetration, thereby reverting to the perpetrator-focused definition common in domestic criminal codes. ${ }^{15}$ The Trial Chamber agreed, defining rape as:

1. the sexual penetration, however slight:

a) of the vagina or anus of the victim by the penis of the perpetrator or any other object used by the perpetrator; or

b) of the mouth of the victim by the penis of the perpetrator;

2. by coercion or force or threat of force against the victim or a third person. ${ }^{16}$

The Trial Chamber arrived at this definition after concluding that, because there was no definition of rape in conventional or customary international law or general principles of international law, it was necessary to look to principles of criminal law common to the major legal systems of the world. ${ }^{17}$ In the Chamber's view, this was the best way to arrive at an accurate definition that satisfies the principle of specificity, nullum crimen sine lege stricta. ${ }^{18}$ The Chamber seemed to imply, through this comment, that the Akayesu approach was not sufficiently specific. ${ }^{19}$ Thus, the Trial Chamber examined the definitions of rape found in the criminal codes and case law of Argentina, Australia, Austria, Bosnia and Herzegovina, Chile, China, England and Wales, France, Germany, India, Italy, Japan, the Netherlands, Pakistan, the Socialist Federal Republic of Yugoslavia, South Africa, Uganda and Zambia at the time of the crimes considered in this case, ${ }^{20}$ and found that, while the national approaches differed,

${ }^{15}$ Furundžija, above n 6, para 174. See also De Brouwer, above n 9, 114.

${ }^{16}$ Furundżija, above n 6, para 185.

${ }^{17}$ Ibid, para 177. For a critique of the resort in this way to national laws, see De Brouwer, above $\mathrm{n}$ 9, 115, who pointed out that the Trial Chamber's consideration of fellatio used international law to ground its conclusion, and that the same international law could have informed the rape discussion. It is puzzling that the judges did not consider the Akayesu definition as amounting to a definition of international criminal law: N Hayes, 'Creating a Definition of Rape in International Law: The Contribution of the International Criminal Tribunals', in S Darcy \& J Powderly (eds), Judicial Creativity at the International Criminal Tribunals (2010) 128, 138.

${ }^{18}$ Furundżija, above n 6, para 177.

${ }^{19}$ De Brouwer, above n 9, 112. This implicit conclusion of the Furundžija trial judges has been pointedly critiqued by MacKinnon, who feels that it is fallacious to argue that 'without such specification, the defendants-guards of concentration camps charged with sexual assault on prisoners in their custody-might not have known with sufficient precision that what they were doing was a crime': C MacKinnon, 'Defining Rape Internationally: A Comment on Akayesu' (2006) 44 Colum J Transnat'l L 940, 946.

${ }^{20}$ Furundžija, above n 6, para. 71 (n 207-14). 
the underlying trend was that domestic laws consider rape to be forced physical penetration of certain body parts. ${ }^{21}$ At the same time, it cautioned against a 'mechanical importation or transposition from national law into international criminal proceedings' because international trials differ in important ways from national trials. ${ }^{22}$ However, this latter point seemed only to apply to the issue of forced fellatio, on which the Trial Chamber noted lack of domestic uniformity as to whether or not it could be considered rape and decided that it should be considered rape under international criminal law. ${ }^{23}$ The end result is that the Furundžija approach can be considered as directly informed by domestic laws but also carrying domestic limitations-the Furundžija definition is narrower than that of Akayesu, as it likely excludes penetration by a perpetrator's finger or tongue, which are not 'objects' under the definition. ${ }^{24}$ It also seems to exclude situations where perpetrators force two victims into fellatio or vaginal or anal rape. $^{25}$

The Furundžija definition was altered just over two years later, in Prosecutor $v$ Kunarac et al. In its judgment, the ICTY Trial Chamber again engaged in a significant manner with domestic laws on rape. The Trial Chamber agreed with the reasoning in Furundzija that precision was required in order to satisfy the principle of legality (again, seemingly critiquing the Akayesu definition as imprecise), and generally agreed with the Furundžija elements of crime. ${ }^{26}$ However, it felt that the element requiring coercion, force or threat of force was 'more narrowly stated than is required by international law. ${ }^{27}$ The Trial Chamber felt that there are other factors that might render an act of sexual penetration non-consensual or non-voluntary on the part of a victim. ${ }^{28}$ It therefore looked to 'general legal principles of law common to the major national legal systems

\footnotetext{
${ }^{21}$ Ibid, paras 179, 181. It did find, however, lack of uniformity on how states dealt with forced oral penetration, and decided that it should be considered rape under international criminal law: ibid, paras 182-4.

22 Ibid, para 178. See also the caution expressed in para 177.

${ }^{23}$ Ibid, paras 182-4.

${ }^{24}$ De Brouwer, above n 9, 115.

${ }^{25}$ Ibid, (n 134). Note that De Brouwer feels that the word 'perpetrator' is meant to include 'victim' in this instance.

${ }^{26}$ Prosecutor $v$ Kunarac et al. (Trial Judgment) (International Criminal Tribunal for the Former Yugoslavia, Trial Chamber, Case No IT-96-23-T \& IT-96-23/1-T, 22 February 2001) para 437 (Kunarac).

${ }^{27}$ Ibid, para 438.

${ }^{28}$ Ibid. These factors include physical or mental incapacity, inducement by surprise or misrepresentation: paras 446-56.
} 
of the world', as had been done in Furundžija. ${ }^{29}$ In order to determine whether there is a 'common denominator' embodying the principles to be adopted in the international context, ${ }^{30}$ the Trial Chamber examined national laws in the same states considered in Furundžija, as well as the laws in place at the relevant time in Bangladesh, Belgium, Brazil, Canada, Costa Rica, Denmark, Estonia, Finland, Korea, New Zealand, Nicaragua, Norway, the Philippines, Portugal, Sierra Leone, Spain, Sweden, Switzerland, the United States and Uruguay. ${ }^{31}$ As a result, the Kunarac Trial Chamber considered that the 'wider or more basic principle' to be drawn from the review of domestic laws was not that force, threat of force and coercion were necessary but that 'absence of consent or voluntary participation'-in other words, a violation of sexual autonomy-is required. ${ }^{32}$ In the Trial Chamber's view, coercion, force and threat of force are evidence of absence of consent, but a focus on non-consent is the central or core concern of domestic legislators. ${ }^{33}$

As a result of its analysis, the Kunarac Trial Chamber adopted a definition of rape slightly altered from that in Furundzija: 'the sexual penetration, however slight: (a) of the vagina or anus of the victim by the penis of the perpetrator or any other object used by the perpetrator or (b) of the mouth of the victim by the penis of the perpetrator, where such sexual penetration occurs without the consent of the victim.' ${ }^{34}$ It continued: '[c]onsent for this purpose must be consent given voluntarily, as a result of the victim's free will, assessed in the context of the surrounding circumstances. ${ }^{, 35}$ The Kunarac definition of rape was upheld on appeal ${ }^{36}$ and has since become the most widely used definition in the ICTY, ICTR and Special Court for Sierra Leone. ${ }^{37}$ The definition has been

\footnotetext{
${ }^{29}$ Ibid, para 439.

${ }^{30}$ Ibid. The 'common denominator' language was quoted from Furundžija, above n 6, para 178.

${ }^{31}$ Kunarac, above n 26, paras 443-5, 447-51, 453-6.

32 Ibid, para 440 . See also paras 441, 457.

${ }^{33}$ Ibid, para 458.

${ }^{34}$ Ibid, para 460.

35 Ibid.

${ }^{36}$ Prosecutor $v$ Kunarac (Appeals Judgment) (International Criminal Tribunal for the Former Yugoslavia, Appeals Chamber, Case No IT-96-23-A \& IT-96-23/1-A, 12 June 2002) para 128.

${ }^{37}$ See e.g. Prosecutor v Kvočka (Trial Judgment) (International Criminal Tribunal for the Former Yugoslavia, Trial Chamber, Case No IT-98-30/1-T, 2 November 2001) paras 177-9; Prosecutor $v$ Semanza (Trial Judgment and Sentence) (International Criminal Tribunal for Rwanda, Trial Chamber III, Case No ICTR-97-20-T, 15 May 2003) paras 344-346; Prosecutor v Taylor (Trial Judgment) (Special Court for Sierra Leone, Trial Chamber II, Case No SCSL-03-01-T, 18 May 2012) para 415.
} 
lauded by some, ${ }^{38}$ and critiqued by others, ${ }^{39}$ for introducing non-consent into the definition of the crime. Some view non-consent as an invalid consideration in the overarching context of genocide, crimes against humanity and war crimes. ${ }^{40}$ For example, Hayes is concerned by the 'circular logic required to address the inappropriateness of discussions of consent given the practical realities of international crimes. ${ }^{41}$ In her view, since the overarching requirements of genocide, crimes against humanity or war crimes will need to be proven prior to the determination of the prohibited act of rape, she asks: "[w]hy, therefore, introduce an element which will be presumed to have been proven once jurisdiction has been established?'42 Others make a related argument that the circumstances surrounding genocide, crimes against humanity and war crimes are so inherently coercive that non-consent must be presumed. ${ }^{43}$ In other words, they feel that the peculiar characteristics of crimes of sexual violence under international law militate in favour of shifting the focus away from consent as an element of the crime. ${ }^{44}$ They feel that the issue of consent might, at most, serve as an affirmative defence that could be raised by the accused in exceptional cases. ${ }^{45}$ On the other hand, some commentators argue that the international and domestic contexts are not entirely dissimilar and therefore a systematic demarcation between the two approaches on non-consent to sexual violence is not necessary, and may in fact create an over-inclusion of victims in a prosecution and negate the rights of the accused. ${ }^{46}$

The analysis of domestic law in Kunarac raises the crucial question of whether the correct domestic law was examined. The Trial Chamber examined laws governing 'ordinary' rape. Schomburg and Peterson have suggested that it would have been more appropriate to examine national laws criminalising sexual acts between individuals in unequal positions of power 'irrespective of

\footnotetext{
${ }^{38}$ See K Boon, 'Rape and Forced Pregnancy Under the ICC Statute: Human Dignity, Autonomy, and Consent' (2001) 32 Colum Hum Rights LR 625, 674-5.

${ }^{39}$ See De Brouwer, above n 9, 119-124.

${ }^{40}$ See Pillay, above n 9, 668 (n 30); W Schomburg \& I Peterson, 'Genuine Consent to Sexual Violence Under International Criminal Law’ (2007) 101 AJIL 121, 125-6; Hayes, above n 17, 150.

${ }^{41}$ Hayes, above $\mathrm{n} 17,150$.

42 Ibid. See also Schomburg \& Peterson, above n 40, 138.

${ }^{43}$ See Schomburg \& Peterson, above n 40, 138.

${ }^{44}$ Ibid, 139.

45 Ibid.

${ }^{46}$ K Engle, 'Feminism and its (Dis)Contents: Criminalizing Wartime Rape in Bosnia and Herzegovina' (2005) 99 AJIL 778, 806. MacKinnon also sees a continuum, albeit differently than Engle: C MacKinnon, Are Women Human? And Other International Dialogues (2006) 225.
} 
the consent of the victim' because such inequality is common during times of war or mass atrocity. ${ }^{47}$ They cite to domestic laws considering, for example, sex between a prison guard and an inmate as better proxies for international laws governing rape between, for example, a soldier and a detained civilian. ${ }^{48}$ This question is valid: if domestic laws are being used as a form of analogy to inform international criminal law, then it is better to use laws that most closely resemble the international context. That said, Schomburg and Peterson acknowledge that, even in these contexts, 'autonomous relationships between individuals remain possible and may even be formed between members of the opposing parties. ${ }^{, 49}$ 'Ordinary' domestic rape laws may indeed be of assistance in drawing the line between criminal and non-criminal acts in those specific circumstances. These seemingly contradictory considerations certainly introduce more complexity into the domestic-to-international conversation.

There is a fourth definition of rape adopted within international criminal law. In 1999 and early 2000, states drafted the ICC's Elements of Crimes, including the elements for the crime against humanity and war crime of rape. ${ }^{50}$ Given the timing of that drafting, state representatives only considered the Akayesu and Furundzija precedents-the Kunarac trial judgment was not issued until 2 February 2001, after the adoption of the finalised Elements of Crime on 30 June 2000.51 Again, domestic laws and approaches formed a central part of the discussion around how to elaborate the elements for the prohibited act of rape. In determining the actus reus, there was strong support for reflecting the Akayesu focus on 'invasion' of the victim's body (i.e. defining the crime from the victim's point of view), including the fact that 'invasion' is gender-neutral (thereby permitting prosecutions of male rape). ${ }^{52}$ However, some states also

\footnotetext{
$\overline{47}$ Schomburg \& Peterson, above n 40, 138 -9.

${ }^{48}$ Ibid, 138 (n 119). Another example might be sex between an adult and an individual under a certain age. E.g. Bulgaria's Criminal Code contains an offence for sexual intercourse with a person under 14 years of age under which consent is not a valid defence: $M C v$ Bulgaria (2003) XII Eur Court HR 1, para 72.

${ }^{49}$ Schomburg \& Peterson, above n 40, 125. See also Engle, above n 46, 806, 810.

${ }^{50}$ Preparatory Commission for the International Criminal Court, Addendum, Part II, Finalized Draft Text of the Elements of Crimes, Doc No ICC-ASP/1/3 (adopted 2 November 2000) at 108; ICC, Elements of Crimes, Doc No PCNICC/2000/1/Add.2 (adopted 30 June 2000) arts 7(1)(g)-1, 8(2)(b)(xxii)-1, 8(2)(e)(vi)-1 (Elements of Crimes).

${ }^{51}$ Ibid; Kunarac, above n 26. On the timing of the Preparatory Commission, see $\mathrm{H}$ von Hebel, 'The Making of the Elements of Crimes- Developing Elements of Crimes' in R Lee (ed), The International Criminal Court: Elements of Crimes and Rules of Procedure and Evidence (2001) 8, 8.

${ }^{52}$ E La Haye, 'The Elements of War Crimes-B. Other Serious Violations in International Armed Conflicts, Article 8(2)(b)(xxii)-Rape, Sexual Slavery, Enforced Prostitution, Forced Pregnancy,
} 
'recalled that most national criminal legislation defines the actus reus as forced physical penetration.' ${ }^{53}$ In addition, there was agreement that the constituent elements of rape needed to be defined in detail to create clarity and legal certainty (making it clear that many states were uncomfortable with the broad conceptual Akayesu approach on its own). ${ }^{54}$ Thus, references to 'invasion' and penetration were combined, reflecting an approach meant to incorporate both domestic considerations and international specificities: " $t$ ] he perpetrator invaded ${ }^{55}$ the body of a person by conduct resulting in penetration, however slight, of any part of the body of the victim or of the perpetrator with a sexual organ, or of the anal or genital opening of the victim with any object or any other part of the body. ${ }^{56}$ However, there was a limit to how far domestic approaches were considered: a proposal by a group of Arab states to, in effect, exclude marital rape was rejected. ${ }^{57}$

The intersection of the domestic and the international was also evident in the discussion around the second actus reus element for the ICC's elements of crime-that rape is committed by force, threat of force or coercion-wording clearly taken from the Furundzija definition. Two proposals, from the United States and Switzerland, replicated this language, which the Furundžija trial judgment noted was found in national legislation. ${ }^{58}$ However, states felt that more precision was needed as to the range of circumstances in which force or coercion was present, hence they included an illustrative list formed from observations in Furundzija ${ }^{59}$ and an influential United Nations Special Rapporteur report. ${ }^{60}$ The second constitutive element therefore reads:

Enforced Sterilization, and Sexual Violence', in R Lee (ed), The International Criminal Court: Elements of Crimes and Rules of Procedure and Evidence (2001) 184, 188.

${ }^{53}$ Ibid.

${ }^{54}$ Ibid, 190.

${ }^{55}$ There is a footnote here which states, " $t$ ] he concept of "invasion" is intended to be broad enough to be gender-neutral': ICC Elements of Crimes, above n 50.

${ }^{56}$ Ibid, 8(2)(b)(xxii)-1-War Crime of Rape, element 1.

${ }^{57}$ Proposal submitted by Bahrain, Iraq, Kuwait, Lebanon, the Libyan Arab Jamahiriya, Oman, Qatar, Saudi Arabia, the Sudan, the Syrian Arab Republic, and United Arab Emirates concerning the elements of crimes against humanity, UN Doc PCNICC/1999/WGEC/DP.39, 3 December 1999. This document proposed a supplementary element in Article 7 (1) (g) (1): Rape stating 'Nothing in these elements shall affect natural and legal marital sexual relations in accordance with religious practices or cultural norms in different national laws'; ibid, 1.

${ }^{58}$ La Haye, above n 52, 187; Furundžija, above n 6, paras 180, 185.

${ }^{59}$ Furundžija, above n 6, para 174.

${ }^{60}$ G J McDougall, Special Rapporteur, 'Contemporary Forms of Slavery, Systematic rape, sexual slavery and slavery-like practices during armed conflict', UN Doc E/CN.4/Sub.2/1998/13, 22 June 1998, para 25 . 
The invasion was committed by force, or by threat of force or coercion, such as that caused by fear of violence, duress, detention, psychological oppression or abuse of power, against such person or another person or by taking advantage of a coercive environment, or the invasion was committed against a person incapable of giving genuine consent. ${ }^{61}$

As La Haye notes, "[t]he intention of the drafters here is clearly to point out that coercive circumstances are not restricted to the use of physical force. ${ }^{, 62}$ In addition, the drafters decided not to include non-consent as an element of the crime when coercive circumstances are involved, an approach contrary to that of the later-decided Trial and Appeals Chambers judgments in Kunarac. ${ }^{63}$

The decision to exclude reference to non-consent as an element of crime necessitated that the ICC's Rules of Procedure and Evidence also reflect this approach, leading to controversial discussions. ${ }^{64}$ There was debate as to whether consent could be an affirmative defence if non-consent is not an element of the crime to be proven by the prosecutor. The resulting discussion reflected the tensions outlined earlier as to whether there should be a clear demarcation between domestic and international approaches to rape, in this case on procedural rules surrounding rape. Many state delegates were of the view that it was a misnomer to speak of consent as a defence because genocide, crimes against humanity and war crimes occur in coercive circumstances that negate or vitiate consent. ${ }^{65}$ However, others were of the view that, despite the wording of the ICC's elements of crime for rape, consent is always relevant as a defence (as in many domestic laws). ${ }^{66}$ Yet other state representatives felt that consent might only rarely be relevant due to the special nature of international criminal law, but if there was a possibility that defendants might raise it, it had to be addressed in the Rules. ${ }^{67}$ Once there was agreement that the Rules needed to include something about consent as a defence, domestic concerns arose again: for example, when

${ }^{61}$ ICC Elements of Crimes, above n 50, arts 7(1)(g)-1, 8(2)(b)(xxii)-1, 8(2)(e)(vi)-1-War Crime of Rape, element 2 . The element ends with a footnote, which reads ' $[\mathrm{i}] \mathrm{t}$ is understood that a person may be incapable of giving genuine consent if affected by natural, induced or age-related incapacity....

${ }^{62}$ La Haye, above n 52, 189.

63 Ibid.

${ }^{64}$ Ibid; D Piragoff, 'Evidence', in R Lee (ed), The International Criminal Court: Elements of Crimes and Rules of Procedure and Evidence (2001) 349, 369-384.

${ }^{65}$ Piragoff, above n 64, 370-371, 372.

${ }^{66}$ Ibid, 373.

${ }^{67}$ Ibid. 
the use of a separate hearing was proposed to determine admissibility of defence evidence, those from civil law backgrounds expressed fear that such proceedings would pre-judge the ultimate issue. ${ }^{68}$ Ultimately, a rule permitting an in camera procedure was adopted, along with a rule on when consent cannot be inferred by the Court. ${ }^{69}$ This latter restrictive approach was meant to satisfy both sides (those who felt no defence was appropriate and those who felt the rights of the accused would be compromised without a defence) and to provide a sensitive procedure that avoids, as much as possible, retraumatising the victims while respecting the accused's rights.

The definition of rape adopted in the ICC's Elements of Crime was deeply informed by domestic legal concerns-hence the reference to 'penetration' as rape's defining feature. Yet certain domestic limitations in some rape laws-such as those stating that only women can be rape victims, that only penile penetration is rape, and that rape cannot occur in marriage ${ }^{70}$ - were deliberately not incorporated. In addition, non-consent was not made an element of the crime that must be proven, thereby taking a very different approach than many domestic jurisdictions, although consent can be raised as a defence in certain limited circumstances (as in many domestic jurisdictions). State delegates were influenced by the Akayesu argument that the definition of rape must be responsive to the realities of genocide, crimes against humanity and war crimes, ${ }^{71}$ which often involve forms of brutality intended to add humiliation upon degradation, ${ }^{72}$ and yet there was a desire to incorporate domestic wording to indicate specificity and to satisfy the principle of legality. This reveals a concerted attempt at balancing international contextual differences with domestic "lessons learned, ${ }^{73}$ but these provisions have not yet been tested in a final ICC judgment. ${ }^{74}$

${ }^{68} \mathrm{Ibid}, 374$, those from common law backgrounds were more comfortable with the idea of a voir dire.

${ }^{69}$ Commission for the International Criminal Court, Addendum, Part I, Finalized Draft Text of the Rules of Procedure and Evidence, ICC-ASP/1/3, U.N. Doc. PCNICC/2000/1/Add.1, 2 November 2000, Rules 70 and 72.

${ }^{70}$ Furundžija, above n 6, para 180; Kunarac, above n 26, paras 444, 454-455; M Eriksson, Defining Rape: Emerging Obligations for States Under International Law? (2011) 37, 44-51.

${ }^{71}$ Akayesu, above n 1, para 597.

72 This point was made recently in Taylor, above n 37, para 1196.

${ }^{73}$ The ICC approach was partially followed in Prosecutor $v$ Issa Hassan Sesay et al (Trial Judgment) (Special Court of Sierra Leone, Case No SCSL-04-15-T, 2 March 2009) paras 144-145, perhaps for the same reasons (although the reasons were not articulated).

${ }^{74}$ However, they have been considered at the confirmation of charges stage. See e.g. Prosecutor $v$ Jean-Pierre Bemba Gombo (Decision Pursuant to Article 61(7)(a) and (b) of the Rome Statute on the Charges of the Prosecutor Against Jean-Pierre Bemba Gombo) (International Criminal Court, Case 
The four definitions of rape in international criminal law demonstrate radically differing levels of engagement with domestic rape laws, and are an apt illustration of what Robinson terms the 'fast-paced transnational conversation' in international criminal law. ${ }^{75}$ The Akayesu case represents a rejection of the validity of domestic law to inform the international definition, because the domestic approach of individual rapes was seen as too different from, and therefore not helpful to, the context of mass rape during genocide. ${ }^{76}$ In addition, the focus on the victim's experience as opposed to that of the perpetrator was considered to be progressive: this concentration on the intent of the act, rather than its technicalities, was seen as overcoming the patriarchal limitations of domestic law. ${ }^{77}$ It was also seen as more consistent with the approach to other crimes within international criminal law, and was perceived as avoiding the dangers of relying upon constantly evolving national law. ${ }^{78}$ The Furundżija and Kunarac definitions demonstrate a deep engagement with domestic law, bringing into international law the concern about discerning general principles from evolving domestic approaches to rape. In addition, these definitions bring into international criminal law the debates extant at domestic law about the focus on the perpetrator's actions (or harm to family honour or society) rather than the experience of the victim. ${ }^{79}$ The Kunarac definition in particular also introduced new debates about the validity of including a reference to non-consent (taken from the domestic level) in an international criminal legal definition, ${ }^{80}$ where

\footnotetext{
No ICC-01/05-01/08, 15 June 2009) paras 161-188, especially 167-168 on defence of consent.

${ }^{75}$ D Robinson, 'A Cosmopolitan Liberal Account of International Criminal Law' (2013) 26 LJIL 127, 128.

${ }^{76}$ The Special Rapporteur on Violence Against Women seems to agree: ' $t$ ] he Akayesu definition reconceptualizes rape as an attack on an individual woman's security of person, not on the abstract notion of virtue and not as a taint on an entire family's or village's honour': UN Commission on Human Rights, Integration of the Human Rights of Women and the Gender Perspective: Violence Against Women, Report of the Special Rapporteur on Violence Against Women, its Causes and Consequences, UN Doc E/CN.4/2001/73, 23 January 2001, para 38.

${ }^{77}$ Eriksson, above n 70, 369, notes that in the context of the Rwandan genocide, this definition 'opens the way for a variety of acts that the perpetrator intended to be sexual and the victim experienced as invasive. It is therefore victim-sensitive since it considers the experience of the victim as the starting point.' This may be 'idealistic', 375 .

${ }^{78}$ See Musema (International Criminal Tribunal for Rwanda, Trial Chamber I, Case No ICTR96-13-A, 27 January 2000) para 228: the Akayesu conceptual approach of rape is preferable because of the 'dynamic ongoing evolution of the understanding of rape [in national jurisdictions] and the incorporation of this understanding into principles of international law.'

${ }^{79}$ UN Women, Progress of the World's Women 2011-2012: In Pursuit of Justice (2011) 32-33.

${ }^{80}$ See Hayes, above n 17, 140-148.
} 
the context is already one of genocide, crimes against humanity or war. ${ }^{81}$ The ICC definition seemingly attempts to satisfy the principle of legality through a balancing of these views: a recognition of the special context of international criminal prosecutions and the identification of certain legal elements found in many domestic criminal laws on rape as well as a limited procedure for a defence of consent. While the Kunarac definition is the one most used at the moment within international tribunals, the impending closure of the ICTY, ICTR and Special Court for Sierra Leone may result in the ICC's elements becoming more influential. ${ }^{82}$ This may ultimately be positive, as it would bring consistency to international law and would also provide an inclusive definition capturing vaginal, oral or anal penetration of a victim by a perpetrator, as well as less common harms such as when a perpetrator uses a finger to effect penetration, or a male victim is forced to use his penis to penetrate (either vaginally, orally or anally) a male or female perpetrator. ${ }^{83}$

These differing approaches illustrate that there is an underlying friction within international criminal law-at least when considering rape-that has not yet been definitively resolved: when should international criminal law necessarily be unique in its approach and when is it useful for it to be informed by domestic law? This is most clear in the discussion over whether the context of genocide, crimes against humanity and war crimes is so fundamentally different from that of 'everyday' rape that domestic notions of rape are inapplicable. Despite the central role played by domestic law in its analysis, the Furundžija trial judgment cautioned against a 'mechanical importation or transposition from national law into international criminal proceedings' because international trials differ in important ways from national trials. ${ }^{84}$ Schomburg and Peterson, and many state delegates involved in drafting the ICC's Elements of Crimes, felt similarly that there is necessarily a difference between the international criminal law approach to rape and the practice under some domestic criminal laws, and this difference 'pays heed to the nature of international criminal law

\footnotetext{
${ }^{81}$ See Schomburg \& Peterson, above n 40, 125, 139.

82 The United Nations Security Council requested the ICTY and ICTR to 'take all possible measures to expeditiously complete all their remaining work ... no later than 31 December 2014': SC Res 1966, 22 December 2010, op para 3. The mandate of the Special Court for Sierra Leone will end after the completion of the 2013 appeal in the Taylor case: Special Court for Sierra Leone, Ninth Annual Report of the President of the Special Court for Sierra Leone June 2011-May 2012 (2012) 27.

${ }^{83}$ See V Oosterveld, 'Gender and the Charles Taylor Case at the Special Court for Sierra Leone' (2012) 19 William \& Mary J of Women and the Law, 7, 12-13, for a discussion of this in the context of the Special Court for Sierra Leone.

${ }^{84}$ Furundžija, above n 6, para 178. See also the caution expressed in para 177.
} 
as a legal system sui generis' ${ }^{85}$ This has been echoed in critiques of other areas of international criminal law by authors such as Drumbl and Osiel. ${ }^{86}$ However, there are others who fear that, by deeming sexual violence amounting to genocide, crimes against humanity or war crimes as 'extraordinary', this type of violence becomes conceptually divorced from so-called 'ordinary' sexual violence to the detriment of both forms (and potentially to the detriment of the principle of legality). ${ }^{87}$ The circumstances that contribute to 'everyday rape'-namely, widespread gender discrimination-also contribute to rape during genocide, war or mass atrocity. The need for further theorisation is also clear in the discussion around whether regular domestic rape laws, or only domestic rape laws considering inherently unequal power relationships, should inform international criminal law. Finally, the tension is also evident, even if largely implicit, in the rejection of discriminatory rape laws as a basis for determining general principles of law for the purposes of delineating international criminal law.

Domestic law has unmistakably informed international criminal law's definitions of rape, but it has also influenced decision-makers' assumptions. Both the Furundżija and Kunarac trial judgments acknowledged that certain domestic rape laws excluded male victims, or rape within marriage, from the definition of rape ${ }^{88}$ Other examples of domestic rape laws of concern are those that require costly medical certificates, ${ }^{89}$ require corroboration of the rape victim's testimony, enable perpetrators to escape prosecution and punishment by marrying their victims, or subject victims of rape to prosecution for moral crimes or defamation. ${ }^{90}$ Clearly, some domestic laws (or related police practices or judicial judgments) on sexual violence operate under inaccurate stereotypes. For example, in many national jurisdictions, there exists a 'false stereotype of women as non-credible complainants of sexual abuse unless they complain at the first opportunity. ${ }^{91}$ When

\footnotetext{
${ }^{85}$ Schomburg \& Peterson, above n 40, 139.

${ }^{86}$ M Drumbl, Atrocity, Punishment, and International Law (2007) 8, 24 and 38; M Osiel, Making Sense of Mass Atrocity (2009) 8.

${ }^{87}$ F Ni Aoláin, 'Gendered Harms and their Interface with International Criminal Law: Norms, Challenges and Domestication' (2013) U Minn Law School Legal Studies Research Paper Series Research Paper No. 13-19, 16.

${ }^{88}$ Furundžija, above n 6, para 180; Kunarac, above n 26, paras 444, 454-455.

${ }^{89}$ For example in Côte d'Ivoire: Sexual violence in conflict: report of the Secretary-General, UN Doc. A/67/792-S/2013/149, 14 March 2013, para 35.

${ }^{90}$ Report of the Human Rights Council on its twenty-third session, UN Doc A/HRC/23/2, 27 August 2013, 75 (HRC Res 23/25 at para 8).

${ }^{91}$ R Cook \& S Cusack, Gender Stereotyping: Transnational Legal Perspectives (2010) 81.
} 
these domestic practices are used to inform-consciously or not-international criminal law, they may lead to poorly reasoned decisions.

\subsection{The characterisation of rape evidence}

An examination of two cases-one from the Special Court for Sierra Leone, and one from the ICTR-reveals that widely-held domestic misconceptions about sexual violence have been imported into international criminal proceedings, thereby negatively affecting the characterisation of rape evidence. The first example relates to Prosecutor $v$ Fofana and Kondewa, popularly known as the Civil Defence Forces or CDF case, at the Special Court for Sierra Leone. In that case, the Prosecutor attempted to amend the CDF indictment to include charges of rape as a crime against humanity, sexual slavery as a crime against humanity, forced marriage as a crime against humanity (under the category of other inhumane acts) and outrages upon personal dignity as a war crime. ${ }^{92}$ This was rejected by a majority of the Trial Chamber on the basis that adding such charges would result in undue delay prejudicing the rights of the accused to a fair and expeditious trial and amount to an abuse of process that would bring the administration of justice into disrepute. ${ }^{93}$ As a result, the Prosecutor brought a subsequent motion to ask the Trial Chamber if he could introduce evidence of gender-based violence (including sexual violence) to prove the existing charges of the crime against humanity of inhumane acts and the war crime of cruel treatment. ${ }^{94}$ Again, two of the three judges rejected this request, even though it was consistent with the practice of other international criminal tribunals. ${ }^{95}$

92 Prosecutor $v$ Sam Hinga Norman et al, (Prosecution Request to Amend the Indictment against Samuel Hinga Norman, Moinina Fofana and Allieu Kondewa) (Special Court of Sierra Leone, Case No SCSL-04-14-PT, 2004).

${ }^{93}$ Prosecutor $v$ Sam Hinga Norman et al. (Decision on Prosecution Request for Leave to Amend the Indictment) (Special Court of Sierra Leone, Case No SCSL-04-14-PT, 20 May 2004) para 10(c). For a critique of this decision, see V Oosterveld, 'The Special Court for Sierra Leone's Consideration of Gender-based Violence: Contributing to Transitional Justice?' (2009) Hum Rights Rev 73, 89-96.

${ }^{94}$ Prosecutor $v$ Sam Hinga Norman et al (Reasoned Majority Decision on Prosecution Motion for a Ruling on the Admissibility of Evidence) (Special Court of Sierra Leone, Case No SCSL-04-14-PT, 24 May 2005) para 3.

${ }^{95}$ Prosecutor $v$ Sam Hinga Norman et al (Decision on the Urgent Prosecution Motion Filed on the $15^{\text {th }}$ of February 2005 for a Ruling on the Admissibility of Evidence) (Special Court of Sierra Leone, Case No SCSL-04-14-PT, 23 May 2005); Prosecutor v Sam Hinga Norman et al (Reasoned Majority Decision on Prosecution Motion for a Ruling on the Admissibility of Evidence) (Special Court of Sierra Leone, Case No SCSL-04-14-PT, 24 May 2005). The proposal of the Prosecutor is consistent with the 
These decisions led to two indications that discriminatory assumptions present in some domestic systems may have influenced the majority judges' reasoning. First, the majority judges seemed to enforce a higher standard on the admission of evidence of sexual violence and forced marriage than they did for other kinds of evidence, by proactively (and, in some cases, prospectively) expunging from the record actual evidence of these acts, evidence that might be about these acts, and evidence that was potentially linked to these acts. ${ }^{96}$ This imposition of a higher standard on evidence of rape has been noted in domestic rape cases in many jurisdictions. ${ }^{97}$ Second, and linked to (and perhaps underlying) the first point, one of the judges reasoned that 'gender evidence' (in this case, referring to evidence of sexual violence and forced marriage) amounts to 'prejudicial evidence' because it is 'of a nature [as] to cast a dark cloud of doubt on the image of innocence that the Accused enjoys under the law until the contrary is proved. ${ }^{\prime 98}$ This regressive language is reminiscent of past assumptions in many domestic jurisdictions (and, unfortunately, present assumptions in others) that allegations of rape and other forms of sexual violence are somehow less reliable (more likely to be false $)^{99}$ and yet more damaging for a male accused than other types of allegations. ${ }^{100}$ This assumption was explicitly repudiated by the Special Court's Appeals Chamber: 'the right to a fair trial enshrined in Article 17 of the Statute

practice of other international criminal tribunals: Prosecutor $v$ Sam Hinga Norman et al (Dissenting Opinion of Judge Pierre Boutet on Decision on Prosecution Motion for a Ruling on the Admissibility of Evidence) (Special Court of Sierra Leone, Case No SCSL-04-14-PT, 9 December 2005) paras 7-9.

${ }^{96}$ Oosterveld, above n 93, 92-93; S Kendall \& M Staggs, Silencing Sexual Violence: Recent Developments in the CDF Case at the Special Court for Sierra Leone (28 June 2005) 16-23, <http://wcsc.berkeley.edu/wp-content/uploads/Papers/Silencing_Sexual_Violence.pdf> [accessed 8 November 2013]. On the negative effects of the majority judicial decisions see M Staggs Kelsall and S Stepakoff, "When We Wanted to Talk About Rape”: Silencing Sexual Violence at the Special Court for Sierra Leone' (2007) International Journal of Transitional Justice 355.

${ }^{97}$ See McGlynn describes higher standards with respect to proving consent in England and Wales: C McGlynn, 'Feminist Activism and Rape Law Reform in England and Wales' in C McGlynn and V Munro, Rethinking Rape Law: International and Comparative Perspectives (2010) 140, 143-150.

${ }^{98}$ Prosecutor $v$ Sam Hinga Norman et al (Separate Concurring Opinion of Hon. Justice Benjamin Mutanga Itoe, Presiding Judge, on the Chamber Majority Decision on Prosecution Motion for a Ruling on the Admissibility of Evidence) (Special Court of Sierra Leone, Case No SCSL-04-14-PT, 24 May 2005) para 78(vi).

99 T Inal, Looting and Rape in Wartime: Law and Change in International Relations (2013) 144.

${ }^{100}$ This is part of the bundle of 'rape myths', see e.g. F Shen, 'How We Still Fail Rape Victims: Reflecting on Responsibility and Legal Reform' (2011) 22 Colum J of Gender and Law 1, 9-27 on rape myths and 23-24 on how these myths are applied through the 'just world theory' prism and are often employed unconsciously. On rape myths that victims are not reliable, see McGlynn, above n 97, 145. 
cannot be violated by the introduction of evidence relevant to any allegation in the trial proceedings, regardless of the nature or severity of the evidence. ${ }^{101}$ Despite this admonition, the experience of the Special Court for Sierra Leone in the CDF case demonstrates that discriminatory assumptions about sexual violence formed at the domestic level can permeate international criminal proceedings.

A different example can be seen at the ICTR in the case of Prosecutor $v$ Rukundo. The ICTR's Trial Chamber had originally convicted Rukundo, an ordained priest and military chaplain for the Rwandan Armed Forces, of committing genocide by causing serious mental harm to a young Tutsi woman by sexually assaulting her in May 1994 at the Saint Léon Minor Seminary in Gitarama prefecture. ${ }^{102}$ The victim had testified that, on Rukundo's arrival at the seminary, she asked if he could hide her. ${ }^{103}$ He responded that he could not help her because her entire family had to be killed. ${ }^{104}$ She assisted him in carrying some items to his room, in the hope that he would change his mind and hide her, but once at the room, he locked the door, placed his pistol on the table, forced the young woman into the bed, opened the zipper to his trousers, and tried to have sexual intercourse. ${ }^{105}$ He was unsuccessful in raping her, so he instead rubbed himself against her until he ejaculated. ${ }^{106}$ The Trial Chamber held that the act was of a sexual nature taking place under coercive circumstances in which the Tutsi refugees at the seminary were regularly abducted and killed. ${ }^{107}$ A majority of the Trial Chamber concluded that the young woman had suffered serious mental harm, considering the "highly charged, oppressive and other circumstances surrounding the sexual assault.' ${ }^{108}$ Given the totality of the circumstances, a majority of the Trial Chamber convicted Rukundo of committing genocide through the sexual assault. ${ }^{109}$ However, a majority of the Appeals Chamber reversed this conviction. It reasoned that 'genocidal intent is not the only reasonable inference to be drawn from Rukundo's assertion [that the

\footnotetext{
${ }^{101}$ Prosecutor v Fofana and Allieu Kondewa (Appeals Judgment) (Special Court for Sierra Leone, Appeals Chamber, Case No SCSL-04-14-A, 28 May 2008) para 446.

${ }^{102}$ Prosecutor v Rukundo (Trial Chamber Judgment) (International Criminal Tribunal for Rwanda, Trial Chamber II, Case No ICTR-2001-70-T, 27 February 2009) paras 4, 574-6.

${ }^{103}$ Ibid, para 373 .

${ }^{104}$ Ibid.

${ }^{105}$ Ibid.

${ }^{106}$ Ibid.

${ }^{107}$ Ibid, paras 381, 383-5.

${ }^{108}$ Ibid, paras 388-389.

${ }^{109}$ Ibid, para 576.
} 
young woman's family had to be killed].'110 The Appeals Chamber majority held that the act committed against the young woman was 'qualitatively different from the other acts of genocide perpetrated by Rukundo', such as the search for Tutsis on the basis of identity cards and lists and their subsequent killing or assault. ${ }^{111}$ Instead, the Appeals Chamber majority considered the sexual assault of the young woman by Rukundo to be 'unplanned and spontaneous', and therefore 'an opportunistic crime that was not accompanied by the specific intent to commit genocide. 112 As a result, it reduced the Trial Chamber's 25 year sentence to 23 years. $^{113}$

Judge Pocar issued a partially dissenting opinion that should be applauded for its sensitivity to combating false stereotypes around sexual violence and a more accurate characterisation of sexual violence in the context of international criminal law. In his view, the majority's 'alternative explanation for Rukundo's utterances before the sexual assault is not reasonable':114 these words 'clearly conveyed Rukundo's knowledge that his victim was Tutsi and that she and other members of her family should be killed for this reason alone.115 This was 'compelling evidence' of Rukundo's genocidal intent at the time of the assault, 'in particular coupled with the serious nature of his crime and the campaign of massive violence directed against Tutsis in the area in which he was found to have participated.'116 Judge Pocar also felt that the majority's differentiation of Rukundo's sexual assault from his other acts of genocide was unreasonable. ${ }^{117}$ In his view, the majority 'does not fully appreciate the seriousness of the crime' of sexual assault-it is not qualitatively different from other prohibited acts (such as killings and serious bodily injury) for which Rukundo has been held responsible. ${ }^{118}$ In his view, the majority's reference to the sexual assault as merely 'opportunistic' incorrectly confuses motive and intent: even if the perpetrator's motivation is entirely sexual, it does not follow that the perpetrator does not have the requisite intent (in this case, genocidal intent) or that his conduct does not

\footnotetext{
${ }^{110}$ Rukundo v Prosecutor (Appeals Judgment) (International Criminal Tribunals for Rwanda Appeals Chamber, Case No ICTR-2001-70-A, 20 October 2010) para 235.

${ }^{111}$ Ibid, para 236.

${ }^{112}$ Ibid.

${ }^{113}$ Ibid, para 269.

${ }^{114}$ Ibid, para 3 (Judge Pocar).

${ }^{115}$ Ibid.

${ }^{116}$ Ibid.

${ }^{117}$ Ibid, para 4.

${ }^{118}$ Ibid.
} 
cause severe pain and suffering. ${ }^{119}$

The reasoning of the majority of the Appeals Chamber reflects similar dismissals at the domestic level of sexual violence as a 'private' act of lust. ${ }^{120}$ The result is that, just as often happens at the domestic level, the ICTR in this case missed the opportunity to contextualise the acts of Rukundo as part of overarching gender discrimination. Erroneous assumptions seem to have informed the majority reasoning in the ICTR's Rukundo case (that sexual violence is mainly a 'private' or opportunistic act) and the Special Court for Sierra Leone's $C D F$ case (that rape allegations against accused persons are somehow both less reliable and more damaging). When these discriminatory assumptions are transposed to the international level, they not only lead to flawed judgments, they also set regressive precedent, potentially prejudicing future sexual violence prosecutions.

\section{The influence of international criminal law on domestic criminal law}

Part 1 illustrated ways in which domestic criminal law on sexual violence, and assumptions inherent within certain iterations of that law, have had an impact on international criminal law. This Part discusses how the conversation is (somewhat) mutual, albeit much more diffuse and therefore harder to track, in its flow from the international to the domestic. It also discusses the potential for a much wider international-to-domestic conversation as a result of state implementation of the Rome Statute of the ICC.

The most obvious measure of international-to-domestic impact comes in the adoption of international legal precepts within domestic law. There is anecdotal evidence that certain international criminal law approaches to sexual violence have been transposed into domestic law. For example, the Akayesu definition of

\footnotetext{
${ }^{119}$ Ibid, para 10.

${ }^{120}$ On rape (such as rape within marriage) viewed as a 'private' act, see H Combrinck, 'Rape Law Reform in Africa: 'More of the Same' or New Opportunities?' in C McGlynn \& V Munro (eds), Rethinking Rape Law: International and Comparative Perspectives (2010) 122, 123. In the refugee law context see V Oosterveld, Women and Girls Fleeing Conflict: Gender and the Interpretation and Application of the 1951 Refugee Convention, UN Doc PPLA/2012/06, September 2012, 22-5, < http://www.refworld.org/cgi-bin/texis/vtx/rwmain?page=search\&doc id $=504 \mathrm{dcb} 172 \&$ skip $=0 \&$ query $=$ oosterveld $>$ [accessed 18 October 2013].
} 
rape has been adopted in a few domestic jurisdictions. ${ }^{121}$ Moreover, many states have implemented the ICC's crimes, including the prohibited acts of rape and other forms of sexual and gender-based violence, into domestic law. ${ }^{122}$ Some have even incorporated or accorded status to the ICC's Elements of Crimes, and therefore their specific definitions of rape and other prohibited acts. ${ }^{123} \mathrm{Ni}$ Aoláin documents 'evidence of significant modifications to domestic laws related to sexual violence, trafficking, stalking, and domestic violence in states that have ratified the International Criminal Court statute. ${ }^{.124}$ Of the 122 States Parties, only 27 have not introduced any subsequent domestic legislation addressing violence against women; however, it is not clear how closely the domestic legislation accords with the international definitions of sexual violence crimes, nor is it clear that these changes are all directly in response to the Rome Statute. ${ }^{125}$ In addition, it appears that at least some of these states have chosen more restrictive definitions of rape than found in international criminal law. ${ }^{126}$ This latter point has been confirmed by Chappell, Grey and Waller, who created a database of domestic definitions of 'ordinary' sexual violence crimes and found that '[i]n relation to rape, most penal codes contain a narrower definition than under the ICC's Elements of Crimes." ${ }^{127}$ For example, '[w]hereas the Elements of Crimes defines rape as vaginal, oral or anal penetration of the victim, as well as forced sexual penetration of the perpetrator by the victim, national penal codes often define rape in terms of vaginal penetration only', require proof of the victim's non-consent, or categorise rape as a crime against the victim's honour and not as a physical and psychological violation. ${ }^{128}$

Another example of the flow of legal norms on sexual violence from the international to the domestic is seen in Sierra Leone. In three of its cases, the Special Court for Sierra Leone brought a great deal of focus to the various

\footnotetext{
${ }^{121}$ See Pillay, above $\mathrm{n} 9,667$, who notes that the Akayesu definition has been incorporated 'virtually verbatim' in South Africa, California and Illinois.

${ }^{122}$ Eriksson, above n 70, 433.

${ }^{123}$ Ibid (citing the United Kingdom and New Zealand).

${ }^{124} \mathrm{Ni}$ Aoláin, above n 87, 9.

${ }^{125}$ Ibid, 17-18, 21.

${ }^{126}$ See Eriksson, above n 70, 433 (provides the example of Bosnia-Herzegovina). See also examples of recent law reform in which restrictive definitions of rape were adopted include Kenya and Ethiopia (failing to criminalize marital rape): Combrinck, above n 120, 131.

${ }^{127}$ L Chappell, R Grey \& E Waller, 'The Gender Justice Shadow of Complementarity: Lessons from the International Criminal Court's Preliminary Examinations in Guinea and Colombia' (2013) 7 Int'l J of Trans Justice 9.

${ }^{128}$ Ibid.
} 
forms of sexual violence that took place against civilian women, girls, men and boys during the civil war. ${ }^{129}$ For example, it outlined typologies of rape-such as gang rape, rape in public, rape with objects, and forced sexual intercourse between captured civilians-and the institutionalised nature of sexual slavery by the rebels. ${ }^{130}$ This brought increased attention to sexual violence more generally in Sierra Leone and seems to have contributed to law reform efforts culminating in the adoption of the Sexual Offences Act 2012. ${ }^{131}$ That Act protects a wide variety of individuals who were previously effectively or actually unprotected in law (such as spouses, children and mentally disabled individuals) and criminalises a wide variety of behaviour that was previously largely overlooked, such as rape inside and outside of marriage, non-consensual sexual touching, incest and sexual harassment. ${ }^{132}$

These examples of actual international-to-domestic impact (although limited), however, indicate the potential for much larger future impact inherent within the Rome Statute of the ICC and its Elements of Crimes. The Rome Statute is governed by the doctrine of complementarity, under which the ICC can only intervene if and when domestic jurisdictions fail to bring genuinely to justice those suspected of having committed the crimes listed in the Rome Statute. ${ }^{133}$ Currently, the Rome Statute has been ratified by 122 states, ${ }^{134}$ and this number is expected to increase in the future. Therefore, more than half of all UN Member States have an incentive to implement domestic laws ensuring that they can pros-

\footnotetext{
${ }^{129}$ Taylor, above n 37, paras 415-32, 874-1191, 1964-2192; Sesay (Special Court of Sierra Leone, Case No SCSL-04-15-T, 2 March 2009) paras 143-77, 1283-1309, 1459-75, 1575-83; Prosecutor v Sesay (Appeals Judgment) (Special Court for Sierra Leone, Appeals Chamber, Trial Chamber II, Case No SCSL-04-15-A, 26 October 2009), paras 726-41; Prosecutor v Brima et al (Trial Judgment, Case No SCSL-04-16-T, 2007) paras 92-95, 691-722, 966-1188; Prosecutor v Brima (Appeals Judgment) (Special Court for Sierra Leone, Appeals Chamber, Case No SCSL-04-16-T, 22 February 2008), paras 88-110.

${ }^{130}$ See e.g. Taylor, above n 37, paras 894-5, 903, 913-14, 919, 927, 930-32, 961, 966, 970-2, 980-1, 989, 992, 999, 1007, 1015-6.

${ }^{131}$ Sexual Offences Act 2002 (Sierra Leone); V Oosterveld, notes on discussions at 'Expert Group Meeting on the Legacy of the Special Court for Sierra Leone', International Center for Transitional Justice and the Special Court for Sierra Leone (6-7 February 2013, Freetown) (on file with author).

${ }^{132}$ Sexual Offences Act 2002, above n 131, ss 5-10, 13, 19-34.

${ }^{133}$ V Nerlich, 'ICC (Complementarity)' in A Cassese (ed), The Oxford Companion to International Criminal Justice (2009) 346, 346; Rome Statute of the International Criminal Court, opened for signature on 17 July 1998, 2187 UNTS 90 (entered into force 1 July 2002), Art. 17.

${ }^{134}$ International Criminal Court, States Parties to the Rome Statute to the International Criminal Court, <http://www.icc-cpi.int/en_menus/asp/states\%20parties/Pages/the\%20states\%20partie s\%20to\%20the\%20rome\%20statute.aspx> [accessed 18 October 2013].
} 
ecute genocide, crimes against humanity and war crimes, if they wish to retain jurisdiction. On the issue of sexual violence, if a state has a restrictive definition of rape (for example, a definition which excludes the possibility that men or boys can be victims of rape), ${ }^{135}$ it may be found by the ICC as unable or unwilling to investigate or prosecute genuinely the crime against humanity or war crime of rape, and the state may lose jurisdiction. ${ }^{136}$ This possibility provides motivation for states to reform outdated sexual violence laws, at least for the purposes of prosecuting sexual violence taking place in the context of genocide, crimes against humanity and war crimes. Such steps may also prompt a review of existing laws governing rape as an 'ordinary' crime. ${ }^{137}$ That said, the ICC itself has been criticised for not adequately evaluating the state of domestic laws on sexual violence in comparison to the Rome Statute, thereby creating a 'gender justice shadow of complementarity $^{\prime 138}$ : if this is correct and it continues, then the impetus for reform provided by complementarity will likely diminish.

Domestic implementation of the Rome Statute of the ICC and its Elements of Crimes, or domestic interpretation of the judgments of international criminal tribunals, present the possibility that outdated domestic legislation on sexual violence will be updated on a widespread basis-a possibility already realised in a number of jurisdictions. However, here again some caution is needed. International criminal law is still somewhat unsettled in terms of the definition of rape and is at the early stages of theorising other forms of sexual and gender-based violence (such as forced marriage). ${ }^{139}$ Thus, the same problem exists as for the domestic-to-international flow: international criminal law on sexual violence is still dynamic, so domestic laws incorporating today's approach may become outdated with future international judgments.

\footnotetext{
${ }^{135}$ Sivakumaran has recorded instances of domestic laws with such definitions: see S Sivakumaran, 'Prosecuting Sexual Violence Against Men and Boys' in A-M de Brouwer et al (eds), Sexual Violence as an International Crime: Interdisciplinary Approaches (2013) 79, 82-3.

${ }^{136}$ Eriksson, above n 70, 432, 437.

${ }^{137}$ WHRnet, 'On Women's Initiatives for Gender Justice and the International Criminal Court: An Interview with Brigid Inder' (August 2004) cited in Eriksson, above n 70, 433 (n 2166).

${ }^{138}$ Chappell, Grey and Waller, above $n 127$.

${ }^{139}$ See questions raised in V Oosterveld, 'Forced Marriage and the Special Court for Sierra Leone: Legal Advances and Conceptual Difficulties' (2011) 2 J of Int'l Humanitarian Legal Studies 127.
} 


\section{Conclusion}

This article has explored the ongoing and two-directional interaction between domestic and international criminal law. It has done so by, first, examining the flow from the domestic to the international in the context of the definition of rape and in legal assumptions made around the characterisation of rape in two international criminal tribunals. While there are some positive aspects to this domestic-to-international dialogue, such as the consideration of a wide variety of forms of rape, there are also some key questions that have yet to be answered. Is it accurate to compare domestic law on 'ordinary' rape with international law on rape as part of genocide, crimes against humanity or war crimes? Or should domestic laws on sex between power-imbalanced individuals be the comparator? Is the context of international criminal law so different from that of domestic 'ordinary' crimes that it merits an entirely different definition of rape? Or does such an approach undermine the understanding that there is a continuum of sexual violence from peacetime to war time or times of mass atrocity? ${ }^{140}$ If international criminal law separates itself entirely from domestic laws on rape, will it unacceptably divorce itself from the intentions behind such violence regardless of its context? ${ }^{141}$ And, how best to ensure that inaccurate or discriminatory domestic assumptions about sexual violence do not become embedded within international criminal law?

International criminal law is also informing domestic criminal law on sexual violence, ${ }^{142}$ or has the possibility of doing so, largely due to the influence of domestic implementation of the Rome Statute or domestic application of international criminal tribunal judgments through law reform. As O’Rourke urges, however, it is important to undertake feminist critical-reflective analysis on whether this is a positive norm transfer between international criminal law and domestic law. ${ }^{143}$ The changing nature of international criminal law on sexual violence, which is developing incrementally and which is still under-theorised, may make it difficult for states to determine exactly which precepts should be

\footnotetext{
${ }^{140}$ F Ní Aoláin, D Haynes \& N Cahn, On the Frontlines: Gender, War, and the Post-Conflict Process (2011) 45-9.

${ }^{141}$ For a discussion of the dangers of a complete separation in a wider context, see Robinson, above n $75,129,151-3$.

${ }^{142}$ It should be noted that international criminal law has also informed regional criminal law: see M C v Bulgaria, above n 48, paras 102-7, 163.

${ }^{143}$ For the perspective of transitional justice, see C O'Rourke, 'International Law and Domestic Gender Justice, or Why Case Studies Matter' in M Fineman et al (eds), Feminism and Transitional Justice (2012) cited in Ní Aoláin, above n 87, 18.
} 
borrowed.

The ICTR's original demarcation in Akayesu, between international and domestic criminal law on sexual violence, has a role to play, whether in protecting international criminal law from false domestic stereotypes and discriminatory domestic laws or in allowing context-specific and gender-sensitive development of norms. In other words, both domestic and international law on sexual violence should never be used (by either system) in an uncritical manner without considering the potential impact of their differences in context and specificities. $^{144}$ However, international and domestic criminal law should not be worlds apart, either. Sexual violence in peacetime has similarities to sexual violence in conflict or mass atrocity, as the existence and acceptance of the former permits the latter to take place in exaggerated forms. ${ }^{145}$ Our struggle, as international criminal lawyers, is in trying to balance these realities.

\footnotetext{
${ }^{144}$ On this point more broadly, see A Zammit Borda, 'Precedent in International Criminal Courts and Tribunals' (2013) 2 CJICL 287, 295 and 305.

${ }^{145} \mathrm{~N}$ í Aoláin et al, above n 139, 45-9.
} 